\title{
Effekter av program i skolen for å forebygge psykiske plager Bror Just Andersen ${ }^{1,2}$ og Erik Nord ${ }^{1}$ \\ 1) Nasjonalt folkehelseinstitutt, divisjon for psykisk helse \\ 2) Vestre Viken HF, Barum DPS \\ Korrespondanse: bror.just.andersen@vestreviken.no
}

\begin{abstract}
SAMMENDRAG
Mellom 15 og 20\% av alle ungdommer i Norge har psykiske problemer som går ut over deres fungeringsevne. Mellom 4 og 7\% har så alvorlige plager at de trenger behandling. Mange tør ikke dele problemene med andre.

VIP er et forebyggende program innenfor psykisk helse for elever i videregående skole. Målsetningen er å øke kunnskap om og evne til å gjenkjenne tegn på psykiske problemer og lidelser, og å senke terskelen for å søke hjelp. Vi vurderer her graden av måloppnåelse. Utvalget er 880 elever i Akershus der intervensjonen har blitt gjennomført, sammenliknet med 811 elever fra Vestfold fylke som ikke hadde intervensjonen. Opplysningene er innhentet gjennom spørreskjema før intervensjonen (t0), og 1 (t1), 6, 12 og 24 måneder etter intervensjonen.

Ved hvert tidspunkt ble kunnskapen målt i prosent av maksimum skåre på et sett av indekser. Effektstørrelsen på de enkelte indeksene er estimert i (a) forskjeller i forbedring av prosentskåre og (b) Cohens d. Fra t0 til t1 hadde intervensjonsgruppen signifikant bedre kunnskapsutvikling innenfor "kjennskap til psykiske lidelser" $(10,2 \%$ flere prosentenheter framgang, Cohens $d=0,58)$, "generell kunnskap om psykisk helse" $(4,4 \%-0,30)$, "evne til kopling av symptomer til diagnoser" (3,1\% - 0,34), "kunnskap om hjelpeapparatet innenfor psykisk helse generelt" (11,6\% - 0,51) og "kunnskap om nærmiljøets hjelpeapparat innenfor psykisk helse" $(11,3 \%-0,74)$.

Sammenliknet med effektstørrelsene i andre, tilsvarende studier (mellom 0,01 og 0,3 i Norge og mellom 0,26 og 0,57 i internasjonale undersøkelser) synes effekten av VIP å være god. Tatt i betraktning at kunnskap forvitrer og glemmes over tid, gjenstår det likevel å se om VIP-programmet får varige effekter av en størrelsesorden som er tilfredsstillende, sett $\mathrm{i}$ forhold til det programmet koster.
\end{abstract}

\section{Andersen BJ, Nord E. Effects of programs in school for preventing mental problems. Nor J Epidemiol 2010; 20 (1): 15-22.}

\section{ENGLISH SUMMARY}

Between 15 and $20 \%$ of all young people in Norway have mental problems that impact their daily functioning. Between 4 and $7 \%$ have problems that need treatment. Many of those who have problems do not dare to share them with others.

VIP is a preventive program in mental health in Norway targeted at students in secondary school. It aims at increasing understanding and recognition of mental problems and illness and at lowering thresholds for help seeking. We assess the degree of achievement of these goals. A sample of 880 students in a county where the program had been implemented was compared with a sample of 811 students in a county where the program had not yet been implemented. Data was collected through questionnaires prior to intervention (t0) and at $1(\mathrm{t} 1), 6,12$ and 24 months after intervention.

At each time, knowledge was measured as percentages of top scores on a set of indices. Effect sizes on the various indices are estimated in terms of (a) differences in improvements of percentage scores and (b) Cohen's d. From t0 to $\mathrm{t} 1$, the intervention group showed significantly greater progress in "knowledge of mental disorders" (10.2 percentage units greater progress, Cohen's $d=0.58)$, "general knowledge of mental health" $(4.4 \%, 0.30)$, "ability to link symptoms to diagnosis" $(3.1 \%, 0.34)$, "general knowledge of mental health services" $(11.6 \%$, $0.51)$, and "knowledge of specific community help facilities" $(11.3 \%, 0.74)$.

Compared with effect sizes from similar studies (between 0.01 and 0.30 in Norway and between 0.26 and 0.57 in international surveys), the effect sizes of VIP lie in the higher end of the scale. However, considering that knowledge to some extent is forgotten over time, it remains to be seen if the VIP program has a satisfactory lasting effect compared to its costs.

\section{INNLEDNING}

Mellom 15 og 20\% av alle ungdommer i Norge har psykiske problemer som går ut over deres fungeringsevne. Mellom 4 og 7\% har så alvorlige plager at de trenger behandling $(1,2)$. Bare $15-20$ prosent av ungdommer med betydelige psykiske plager har vært i kon- takt med psykisk helsevern de siste 12 månedene (3).

Psykiske problemer er ofte tabubelagt. Mange tør ikke dele problemene med andre. For lite kunnskap om problemene kan medvirke til at de som er rammet, ikke er klar over hva som plager dem. Om nettverket rundt har den samme kunnskapsmangelen, er muligheten for å få hjelp i primærrelasjonene begrenset. 
Det er evidens for at tidlig hjelp vil kunne gi unge med psykiske lidelser bedre muligheter og minske sjansen for gjentatte, alvorlige sykdomsperioder (4-8). Samtidig er det rimelig å anta at mer kunnskap blant de unge om psykiske lidelser øker sjansene for at tidlig hjelp vil bli søkt.

Skolen synes både organisasjonsmessig og formidlingsmessig som en god arena for forebyggende tiltak. Alle er der på et eller annet tidspunkt, de er der over tid og de er der for å lære. Dette er bakgrunnen for det primærforebyggende programmet "VIP" - Veiledning og Informasjon om Psykisk helse. Intervensjonen ble startet etter initiativ fra brukerrådet på Blakstad sykehus i 1999. Den utøves overfor elever i første klasse i videregående skoler og hadde per januar 2009 56\% dekning blant slike skoler i Norge (9).

VIPs mål er blant annet:

1. Å øke elevenes kunnskapsgrunnlag om psykisk helse og på den måten gjøre elevene bedre i stand til å ta vare på sin egen psykiske helse.

2. Å forbedre de unges evne til gjenkjennelse av signaler på psykiske lidelser.

3. Å senke terskelen for å søke hjelp.

Det er allerede fra oppstart gjennomført tilfredshetsevaluering av intervensjonen, og oppsummerende rapporter fra et tilfeldig utvalg skoler finnes tilgjengelig på intervensjonens nettsider (9). Vi evaluerer imidlertid VIP med hensyn til effekter på de tre ovennevnte målene. I denne artikkelen rapporteres observasjoner på kort sikt, dvs. umiddelbart etter intervensjonens gjennomføring. Vi konsentrerer oss da om effekter av intervensjonen på endring av kunnskap og på evne til gjenkjennelse. Vi spesifiserer effekter etter foreldres utdanning og undersøker også om utfylling av spørreskjema før intervensjonen i seg selv kan ha en effekt. Effekter på lengre sikt, herunder på hjelpsøkeradferd og endring i egenrapportering om psykisk helse (10), vil bli rapportert i senere artikler.

\section{Narmere om intervensjonen}

Intervensjonen starter med en 2 dagers konferanse for hele lærerkollegiet. Deretter gjennomføres to timer med veiledning for kontaktlærerne. Foresatte får informasjon i brev. Lærer og elever arbeider klassevis med tiltakets veiledende materiale, normalt 3-5 timer. Dette blir så fulgt opp gjennom et to timers besøk av en fagperson fra det kliniske feltet i psykiatrisk spesialisthelsetjeneste og skolens helsesøster, og/eller pedagogiskpsykologisk tjeneste. Den delen av intervensjonen som involverer elevene, blir vanligvis gjennomført i løpet av en til to uker. Alle elever får tilbud om én til én samtaler med spesialisthelsetjenesten eller helsesøster, mens skoler og helsesøstre blir tilbudt videre oppfølging og veiledning fra spesialisthelsetjenesten.

Det veiledende materialet består av et hefte med tekst og ulike oppgaver til alle elever. Heftet dreier seg om helsefremmende og sykdomsforebyggende tiltak. Det veksles mellom faktaopplysninger, diskusjoner og brukerhistorier. Heftet er utarbeidet av brukere og fag- personer fra spesialisthelsetjenesten. I intervensjonen lærer elevene kort om hva som regnes som psykiske problemer og lidelser. Det presenteres noe statistikk og en del faktaopplysninger om og kjennetegn ved psykiske lidelser. Det diskuteres grensegang mellom livets utfordringer, når man bør oppsøke hjelp, og det presenteres hvilke hjelpetilbud som finnes nasjonalt og spesielt lokalt.

Det er utarbeidet manualer for gjennomføring i alle deler av prosjektet, og det kreves ingen spesielle forkunnskaper av lærer (nærmere om de enkelte manualer se intervensjonens nettside: http://www.vipweb.no).

Gjennomføringen av tiltaket er tverrfaglig og tverretatlig. Det involverer koordinator for psykisk helse $\mathrm{i}$ kommunen, skolens ledelse og lærere, helsesøster og psykiatrisk spesialisthelsetjeneste. Intervensjonen skiller seg fra mange typer skolebasert forebyggende virksomhet gjennom det sterke fokuset på kunnskapsbasert dialog og ved graden av involvering fra de lokale hjelpeinstanser (9).

\section{MATeriale OG METOder}

\section{Endepunkter}

De målte endepunkter i studien er:

- elevenes kunnskaper om psykiske helse

- elevenes evne til gjenkjennelse av tegn på psykiske lidelser

- elevenes egenrapporterte atferd med hensyn til å søke hjelp

\section{Utvalg}

Intervensjonen ble på utvalgstidspunktet gjennomført i 13 fylker. Ett av disse var Akershus, og intervensjonsgruppen er valgt derfra. Intervensjonsgruppen er framkommet ved stratifisert tilfeldig utvelging, der strata utgjøres av de linjer skolene tilbyr (enten kun studiespesialiserende, eller både studiespesialiserende og yrkesfaglige linjer). Kontrollgruppen ble valgt ut blant skoler i Vestfold, som var et av de fylkene som ikke hadde intervensjonen. Det ble valgt skoler som matchet skoler i intervensjonsgruppen med hensyn til utdanningsnivå i befolkningen mellom 18 og 67, topografi og geografi, inntektsnivå, tilbud innenfor somatisk og psykisk helse og generell helsetilstand. Variablene er hentet fra årboken til Statistisk Sentralbyrå (11). Det var altså tilfeldig trekning til deltakelse i evalueringsprosjektet innenfor hvert av de to geografiske områdene, men ikke randomisering av klasser til henholdsvis intervensjons- og kontrollgruppe.

Følgende skoler ble invitert til å delta:

Akershus: Bjørklangen vgs, Stabekk vgs, Strømmen vgs, Vestby vgs og Valler vgs.

Vestfold: Re vgs, Sande vgs og Thor Heyerdahl vgs.

Alle de forespurte skolene takket ja til deltakelse.

I skoleåret 2006/2007 var det i Akershus i alt 7731 elever i første klasse (VK 1, 16-17år), fordelt på 28 skoler. Av disse 7731 ble 64 klasser med tilsammen 
Figur 1. Prosjektets forskningsdesign.

\begin{tabular}{|c|c|c|c|c|c|c|}
\hline & t 0 & & t 1 & t $2: 6 \mathrm{mnd}$ & t 3: $12 \mathrm{mnd}$ & $\mathrm{t} 4: 24 \mathrm{mnd}$ \\
\hline Gruppe 1 & Pretest & Intervensjon & Posttest 1 & Posttest 2 & Posttest 3 & Posttest 4 \\
\hline Gruppe 2 & Pretest & & Posttest 1 & Posttest 2 & Posttest 3 & Posttest 4 \\
\hline Gruppe 3 & & Intervensjon & Posttest 1 & Posttest 2 & Posttest 3 & Posttest 4 \\
\hline Gruppe 4 & & & Posttest 1 & Posttest 2 & Posttest 3 & Posttest 4 \\
\hline
\end{tabular}

Tabell 1. Antall elever i populasjon og utvalg og antall svar på ulike tidspunkter.

\begin{tabular}{l|ccc|ccc}
\hline & \multicolumn{3}{|c|}{ Akershus } & \multicolumn{3}{c}{ Vestfold } \\
\cline { 2 - 7 } & $\begin{array}{c}\mathrm{t} 0 \\
\text { (gruppe 1) }\end{array}$ & $\begin{array}{c}\text { Nye ved t1 } \\
\text { (gruppe 3) }\end{array}$ & $\begin{array}{c}\text { Totalt ved t1 } \\
\text { (gruppe 1+3) }\end{array}$ & $\begin{array}{c}\text { t0 } \\
\text { (gruppe 2) }\end{array}$ & $\begin{array}{c}\text { Nye ved t1 } \\
\text { (gruppe 4) }\end{array}$ & $\begin{array}{c}\text { Totalt ved t1 } \\
\text { (gruppe 2+4) }\end{array}$ \\
\hline Total populasjon & 7731 & & & 3464 & & 763 \\
Trukket & 730 & 213 & 943 & 206 & 757 & 152 \\
Fylte ikke kriteriene for deltakelse & 20 & 43 & 63 & 12 & 140 & 811 \\
Mottatt spørreskjema & 710 & 170 & 880 & 194 & 617 & 718 \\
Utfylt tilfredsstillende & 567 & 163 & 671 & 148 & 570 & 88,5 \\
Responsrate i \% & 79,9 & 95,9 & 76,3 & 76,3 & 92,4 & \\
\hline
\end{tabular}

943 elever trukket ut som intervensjonsgruppe i evalueringsprosjektet. I Vestfold var det i skoleåret 2006/2007 3464 elever i VK1 fordelt på 10 skoler. Av disse 3464 ble 61 klasser med til sammen 963 trukket ut som kontrollgruppe i evalueringsprosjektet.

Gjennomføring av målinger $\mathrm{i}$ intervensjonsgruppen forut for intervensjon og umiddelbart etter intervensjon ble utført i perioden 26.01.-11.04.07. Målinger i kontrollgruppen ble gjennomført parallelt med dette.

\section{Datainnsamling}

Data ble samlet inn via spørreskjema, se nedenfor.

I både intervensjonsgruppen og kontrollgruppen ble klasser randomisert til to undergrupper. Den ene fikk spørreskjema like før intervensjonstidspunktet (t0), umiddelbart etterpå (t1), og så etter 6,12 og 24 måneder. Den andre gruppen fikk ikke spørreskjema før intervensjonstidspunktet, men for øvrig ved $\mathrm{tl}$ og på de samme tidspunktene seinere $(6,12$ og 24 måneder). Det vises til figur 1 (gruppe 1-4). Formålet med dette "Solomon fire-gruppe designet" $(12,13)$ var å fange opp en tilleggsproblematikk, nemlig om utfylling av spørreskjema før intervensjon i seg selv kunne ha betydning for utfallet (i det følgende referert til som 'sensitiviseringseffekt av pretest').

\section{Sporreskjema}

Det ble brukt to spørreskjemaer. I det første ble elevene bedt om å angi ulike psykiske lidelser som de kjente til. Det andre spørreskjemaet består av 81 spørsmål. I del 1 og 2 måles kunnskap om psykisk helse. I del 3 måles evnen til gjenkjenning av psykiske problemer og de unges atferd ved hjelpsøking. Del 4 er selvrapporteringsskjema fra SDQ-Nor $(14,10)$, der vi har supplert med 5 utsagn om angst og lagt til et spørsmål om primær-/nærmiljøets involveringsgrad i del 2 om dag- lig innvirkning (Impact). Spørsmålene om angst er hentet fra TOPP (15). I del 5 registreres elevens personlige kjennetegn. Det ble høsten 2006 gjennomført en pilot med 50 respondenter fra Eikeli og Dønski vgs for testing av spørreskjemaene. Spørreskjemaene, oppsett og målinger er tilgjengelige på (16).

På hvert av tidspunktene t0 til t4 ble utfylling av spørreskjemaene gjennomført i en skoletime. Lærer delte først ut skjema $1 \mathrm{og}$ samlet inn dette etter $3 \mathrm{mi}$ nutter. Deretter ble skjema 2 delt ut og samlet inn etter 35 minutter. Oppdelingen i skjema 1 og 2 ble gjort for at informasjon i skjema 2 ikke skulle kunne brukes ved besvarelse av skjema 1. Elevene satt enkeltvis og fikk ikke levere utfylt spørreskjema før hele den tilmålte tiden var gått. De som ikke ønsket å delta, ble satt til vanlig skolearbeid.

\section{Frafall og nettoutvalg}

Av det totale utvalget på 135 klasser ble 16 klasser (4 ved t0 og 12 ved t 1 ) tatt ut fordi de ikke fylte kriteriene til gjennomføring. De vanligste grunne var manglende språkforståelse og/eller skriveferdigheter. Ny N ved t0 er derfor 904 og ved t1 1691. Ved t0 ble det rapportert at 47 elever var fraværende. På samme tidspunkt ble det rapportert at 18 elever ved 4 skoler ikke ønsket å delta. Tabell 1 viser frafall og antall tilfredsstillende utfylte spørreskjemaer på ulike trinn i undersøkelsen. Total responsrate for intervensjonsgruppen var 76,3\%, og for kontrollgruppen $88,5 \%$.

\section{Databehandling}

For hvert spørsmål om kunnskap ble det på forhånd bestemt hva som var riktig svar. Tilsvarende ble det for holdnings- og adferdsspørsmål bestemt hva som var mest ønsket holdning eller adferd. Disse 'fasitsvarene' ble bestemt i samråd med tre professorer 
innenfor fagområdet psykisk helse. For hvert spørsmål ble det så beregnet hvor stor prosentandel av intervensjonsgruppen og kontrollgruppen som hadde riktig svar. For adferdsspørsmål ble det beregnet prosentandeler med ønsket adferd.

Det er regnet ut forskjeller mellom intervensjonsgruppen og kontrollgruppen med hensyn til endring $i$ prosentandeler med 'riktige svar' på hvert enkelt spørsmål i spørreskjemaet. Dette er rapportert fullstendig annetsteds (16).

På bakgrunn av spørreskjemaets 81 spørsmål er det for denne artikkelen utarbeidet 7 indekser (mer informasjon, 16):

1. Kjennskap til psykiske lidelser. Omfatter ett spørsmål: Skriv ned de ulike formene for psykiske lidelser du vet om. Skåreskala: 0-12.

2. Generell kunnskap om psykisk helse. Omfatter 6 spørsmål. Eksempel: Hvor stor andel av barn og unge i Norge tror du har psykiske problemer/lidelser? Skåreskala: 0-15.

3. Kunnskap om ulike diagnosers ytringsformer. Omfatter 9 spørsmål. Eksempel: Hvilke av de følgende er kjennetegn på depresjon? Scoreskala: 0-44.

4. Evne til kopling av symptomer til diagnoser. Omfatter ett spørsmål med 25 ledd: Nedenfor er en liste over kjennetegn som kan tyde på at en person har en psykisk lidelse. Skriv til høyre på hver linje hvilken lidelse (evt hvilke lidelser) vedkommende kjennetegn kan være forbundet med. Skåreskala: 050.

5. Tillit til behandlingsmetoder. Omfatter 2 spørsmål. Eksempel: I hvilken grad tror du fagfolk som psykologer og leger kan hjelpe personer som lider av angst? Skåreskala: 0-2.

6. Kunnskap om hjelpeapparatet innenfor psykisk helse generelt. Omfatter 11 spørsmål. Eksempel: Hvor godt kjenner du følgende tilbud? Eks. Barne- og ungdomspsykiatrisk poliklinikk. Skåreskala: 0-30.

7. Kunnskap om nærmiljøets hjelpeapparat innenfor psykisk helse. Omfatter 8 spørsmål. Eksempel: Har dere en helsesøster ved deres skole? Skåreskala: 0-8.

Nedenfor rapporterer vi gjennomsnittskårer på hver indeks i form av prosent av maksimalt mulig skåre på skalaen for den enkelte indeks.

I analysene av det foreliggende datamaterialet har vi benyttet SPSS 14.0. Innledningsvis ble alle faktorer dikotomisert, det ble kjørt frekvensanalyser på enkeltitem/indekser på individ og skolenivå og vi gjorde frekvensanalyser med t-tester på alle fire grupperinger for å teste for eventuell pretest sensitivisering. Deretter har vi målt kvaliteten i skalaene gjennom reliabilitetsanalyser ved Cronbachs Alfa / Kruder-Ricardson (KR20) og Prinsipal komponentanalyse med Varimax rotasjon. Generelt sett har vi holdt oss til Kaisers kriterium med Eigenvalue større enn 1,0, og $\alpha>0,7$. Skala 2, 5 og 7 ligger mellom 0,4 og 0,5 , men de er pragmatiske indekser og har en logisk teoretisk sammenheng for målingen (16).
Vi har gjort t-tester for signifikans på gjennomsnitt ved enkeltspørsmål og indekser, og deretter på samme måte benyttet General Linear Modell for å teste endringer over de to måletidspunktene.

Effektstørrelsene er angitt både i absolutte tall og som forskjeller mellom gjennomsnitt, delt på standardavviket i utvalgene, dvs. Cohens d (17). Vurderingene av effekter er $\mathrm{i}$ henhold til de generelle internasjonale retningslinjer, der 0,2 defineres som en liten effekt, 0,5 som middels effekt og 0,8 som en stor effekt (17).

\section{RESUltater}

Tabell 2 viser personlige kjennetegn i intervensjonsog kontrollgruppe. Det er ikke vesentlige forskjeller når det gjelder kjønnssammensetning, alder, inntektsgivende arbeid eller bosituasjon. Det er heller ikke vesentlige forskjeller når det gjelder husstandsinntekt, men disse tallene er mer usikre ettersom henholdsvis 38,9 og 37,6\% svarer "vet ikke". Det er høyere andel med mer enn fire års universitetsutdanning blant foreldrene $\mathrm{i}$ intervensjonsgruppen, og flere som er født et annet sted enn i Norge.

Tabell 2. Personlige kjennetegn ved t0.

\begin{tabular}{|c|c|c|}
\hline Variabler & Test & Kontroll \\
\hline $\begin{array}{l}\text { Gjennomsnittlig } \mathrm{N} \text { for alle variabler } \\
\quad(\text { tot } \mathrm{N} \text { ved t } 0)\end{array}$ & $\begin{array}{l}N=475 \\
(567)\end{array}$ & $\begin{array}{c}N=123 \\
(148)\end{array}$ \\
\hline Menn & $49,8 \%$ & $53,1 \%$ \\
\hline Kvinner & $50,2 \%$ & $46,1 \%$ \\
\hline Alder (i år) & 16,35 & 16,35 \\
\hline Inntektsgivende arbeid ved siden av skole & $65,1 \%$ & $62,5 \%$ \\
\hline \multicolumn{3}{|l|}{ Bosituasjon } \\
\hline Bor sammen med både mamma og pappa & $69,3 \%$ & $62,7 \%$ \\
\hline $\begin{array}{l}\text { Bor sammen med kun en av foreldrene }+ \\
\text { eventuelt en av foreldrene med ny samboer }\end{array}$ & $22,7 \%$ & $24,5 \%$ \\
\hline Bor i fosterhjem & $0,4 \%$ & $2,4 \%$ \\
\hline \multicolumn{3}{|l|}{ Tot inntekt for husstanden } \\
\hline $0-400$ ' NOK & $2,7 \%$ & $0,0 \%$ \\
\hline $400-800^{\prime} \mathrm{NOK}$ & $35,2 \%$ & $45,1 \%$ \\
\hline $800^{\prime}$ NOK og mer & $23,2 \%$ & $17,3 \%$ \\
\hline Gjennomsnittlig inntekt & $748^{\prime}$ & $613^{\prime}$ \\
\hline \multicolumn{3}{|l|}{ Utdanningsnivå for mor } \\
\hline Grunnskole & $9,2 \%$ & $9,3 \%$ \\
\hline Videregående skole & $24,3 \%$ & $35,5 \%$ \\
\hline Høyskole/Universitet mindre enn 4 år & $27,0 \%$ & $29,9 \%$ \\
\hline Høyskole/Universitet mer enn 4 år & $39,6 \%$ & $25,2 \%$ \\
\hline \multicolumn{3}{|l|}{ Utdanningsnivå for far } \\
\hline Grunnskole & $9,9 \%$ & $9,2 \%$ \\
\hline Videregående skole & $24,0 \%$ & $33,0 \%$ \\
\hline Høyskole/Universitet mindre enn 4 år & $17,8 \%$ & $33,0 \%$ \\
\hline Høyskole/Universitet mer enn 4 år & $48,3 \%$ & $24,8 \%$ \\
\hline \multicolumn{3}{|l|}{ Fødeland } \\
\hline Norge & $91,5 \%$ & $96,1 \%$ \\
\hline Annet land & $5,8 \%$ & $3,1 \%$ \\
\hline \multicolumn{3}{|l|}{ Fødeland, mor } \\
\hline Norge & $86,0 \%$ & $91,5 \%$ \\
\hline Annet land & $13,8 \%$ & $8,5 \%$ \\
\hline \multicolumn{3}{|l|}{ Fødeland, far } \\
\hline Norge & $86,7 \%$ & $94,5 \%$ \\
\hline Annet land & $13,3 \%$ & $5,5 \%$ \\
\hline
\end{tabular}


Tabell 3. Skårer ved t0 og endring fram til t1. Gruppe $1 \mathrm{og} 2$.

\begin{tabular}{|c|c|c|c|c|c|c|c|c|c|c|}
\hline \multirow[t]{2}{*}{ Indekser } & \multicolumn{3}{|c|}{ Intervensjonsgruppe } & \multicolumn{3}{|c|}{ Kontrollgruppe } & \multirow{2}{*}{$\begin{array}{c}\text { Gjennom- } \\
\text { snittlig diff. } \\
\text { i endring, \% } \\
\text { av } \\
\text { maksskåre }\end{array}$} & \multirow[b]{2}{*}{$\begin{array}{l}\text { Std. feil } \\
\text { for diff. i } \\
\text { endring }\end{array}$} & \multirow[b]{2}{*}{$\begin{array}{c}\text { Sig. (2- } \\
\text { halet test) }\end{array}$} & \multirow[b]{2}{*}{$\begin{array}{l}\text { Skåre } \\
\text { skala }\end{array}$} \\
\hline & $\begin{array}{l}\text { Gjennom- } \\
\text { snittlig \% av } \\
\text { maksskåre } \\
\text { ved t0 } \\
\end{array}$ & $\begin{array}{l}\text { Gjennom- } \\
\text { snittlig end- } \\
\text { ring i \% av } \\
\text { maksskåre }\end{array}$ & $\begin{array}{l}\text { Std. feil } \\
\text { for gj. } \\
\text { endr }\end{array}$ & $\begin{array}{c}\text { Gjennom- } \\
\text { snittlig \% av } \\
\text { maksskåre ved } \\
\text { t0 }\end{array}$ & $\begin{array}{l}\text { Gjennom- } \\
\text { snittlig end- } \\
\text { ring i \% av } \\
\text { maksskåre }\end{array}$ & $\begin{array}{l}\text { Std. feil } \\
\text { for gj. } \\
\text { endr }\end{array}$ & & & & \\
\hline $\begin{array}{l}\text { 1. Kjennskap til psykiske } \\
\text { lidelser }\end{array}$ & 28,4 & 20,8 & 0,92 & 24,5 & 10,6 & 1,42 & 10,2 & 1,91 & $0,000 * *$ & $0-12$ \\
\hline $\begin{array}{l}\text { 2. Generell kunnskap om } \\
\text { psykisk helse }\end{array}$ & 65,3 & $-2,3$ & 1 & 63,1 & $-6,7$ & 1,6 & 4,4 & 2,2 & $0,048^{*}$ & $0-15$ \\
\hline $\begin{array}{l}\text { 3. Kunnskap om ulike } \\
\text { diagnosers ytringsformer }\end{array}$ & 59,0 & 3,3 & 0,71 & 60,9 & 1,5 & 1,3 & 1,8 & 1,51 & 0,24 & $0-44$ \\
\hline $\begin{array}{l}\text { 4. Evne til kopling av } \\
\text { symptomer til diagnoser }\end{array}$ & 27,5 & 5,4 & 0,5 & 27,2 & 2,3 & 0,74 & 3,1 & 1 & $0,002 *$ & $0-50$ \\
\hline $\begin{array}{l}\text { 5. Tillit til behandlings- } \\
\text { metoder }\end{array}$ & 92,0 & -2 & 1 & 93,0 & 1,4 & 2 & $-3,4$ & 2,5 & 0,16 & $0-2$ \\
\hline $\begin{array}{l}\text { 6. Kunnskap om } \\
\text { hjelpapparatet innenfor } \\
\text { psykisk helse generelt }\end{array}$ & 32,5 & 8,0 & 0,73 & 31,0 & $-3,6$ & 1,08 & 11,6 & 1,51 & $0,000 * *$ & $0-30$ \\
\hline $\begin{array}{l}\text { 7. Kunnskap om nær- } \\
\text { miljøets hjelpeapparat } \\
\text { innenfor psykisk helse }\end{array}$ & 46,9 & 9 & 0,75 & 43,8 & $-2,3$ & 1,25 & 11,3 & 1,6 & $0,000 * *$ & $0-8$ \\
\hline
\end{tabular}

Tabell 4. Fordeling av enkeltledd i indekser for intervensjons- og kontrollgruppe ved t1.

\begin{tabular}{|c|c|c|c|c|c|c|c|c|c|}
\hline \multirow[b]{2}{*}{ Indeksnr/beskrivelse } & \multirow[b]{2}{*}{ Antall ledd } & \multicolumn{6}{|c|}{ Fordeling av enkeltledd } & \multirow[b]{2}{*}{ Indeks } & \multirow{2}{*}{$\begin{array}{l}\text { Samlet vurde- } \\
\text { ring av effekt }\end{array}$} \\
\hline & & $\mathrm{K}>\mathrm{I}$ & $\mathrm{K}=\mathrm{I}$ & $\mathrm{I}>\mathrm{K}$ & $\mathrm{I}>\mathrm{K}^{*}$ & $\mathrm{I}>\mathrm{K}^{\mathrm{V}}$ & $\mathrm{I}>\mathrm{K}^{* \mathrm{~V}}$ & & \\
\hline $\begin{array}{l}\text { 1. Kjennskap til psykiske } \\
\text { lidelser }\end{array}$ & 1 & & & & & & 1 & $I^{* *}$ & Betydelig \\
\hline $\begin{array}{l}\text { 2. Generell kunnskap om } \\
\text { psykisk helse }\end{array}$ & 14 & 2 & & 8 & & 4 & & $I^{*}$ & Stor \\
\hline $\begin{array}{l}\text { 3. Kunnskap om ulike } \\
\text { diagnosers ytringsformer }\end{array}$ & 48 & 18 & & 27 & & 5 & & $\mathrm{~K}$ & Liten \\
\hline $\begin{array}{l}\text { 4. Evne til kopling av } \\
\text { symptomer til diagnoser }\end{array}$ & 25 & & & & & & 1 & $I^{*}$ & Betydelig \\
\hline $\begin{array}{l}\text { 5. Tillit til } \\
\text { behandlingsmetoder }\end{array}$ & 4 & 2 & & & & & & $\mathrm{~K}$ & Svært liten \\
\hline $\begin{array}{l}\text { 6. Kunnskap om hjelpe- } \\
\text { pparatet innen psykisk } \\
\text { helse generelt }\end{array}$ & 10 & & & 6 & 4 & & & $I^{* *}$ & Betydelig \\
\hline $\begin{array}{l}\text { 7. Kunnskap om nær- } \\
\text { miljøets hjelpeapparat } \\
\text { innen psykisk helse }\end{array}$ & 8 & & & 2 & 4 & & 2 & $I^{* *}$ & Betydelig \\
\hline
\end{tabular}

Tabell 3 viser indeksskårer ved t0 i gruppe 1 (intervensjon) og gruppe 2 (kontroll) og endring i disse skårene fram til t1. Disse to gruppene er teoretisk like mht sensitivisering gjennom pretest. Intervensjonsgruppen har gjennomsnittlig signifikant større fremgang når det gjelder kjennskap til psykiske lidelser $(10,2 \%$ flere prosentenheter framgang, Cohens $\mathrm{d}=0,58)$, generell kunnskap om psykisk helse $(4,4 \%-0,30)$, evne til kopling av symptomer til diagnoser $(1,8 \%$ - 0,34$)$, kunnskap om hjelpeapparatet innenfor psykisk helse generelt $(11,6 \%-0,51)$ og kunnskap om nærmiljøets hjelpeapparat innenfor psykisk helse $(11,3 \%-0,74)$.

I tabell 4 utdypes bildet i tabell 3 . Innenfor hver indeks vises hvordan enkeltleddene fordelte seg $\mathrm{mht}$ forskjell mellom intervensjons- og kontrollgruppen når det gjelder endring i skåre fra t0 til t1. Kategoriene spenner fra at kontrollgruppen hadde mer positiv utvikling enn intervensjonsgruppen $(\mathrm{K}>\mathrm{I})$ til at intervensjonsgruppen hadde vesentlig $\left(^{v}\right)$ og statistisk signifikant mer positiv utvikling $\left(\mathrm{I}>\mathrm{K}^{*}{ }^{*}\right)$. For eksempel var det 14 ledd $\mathrm{i}$ indeks 2 om generell kunnskap om psykisk helse. På to av disse hadde kontrollgruppen mer positiv utvikling fra t0 til t1 enn intervensjonsgruppen. På åtte andre hadde intervensjonsgruppen mer positiv utvikling, men uten at forskjellen i endring var vesentlig eller statistisk signifikant. På fire andre ledd hadde intervensjonsgruppen vesentlig mer positiv utvikling. I sum er bildet en bekreftelse av tabell 3: In- 
Tabell 5. Betydningen av fars utdanningsnivå for effekt.

\begin{tabular}{|c|c|c|c|c|c|c|c|c|c|c|c|c|c|}
\hline \multirow[b]{2}{*}{ Indekser } & \multirow[b]{2}{*}{$\begin{array}{c}\text { Alle } \\
\\
\text { Gjennom- } \\
\text { snittlig diff. } \\
\text { i endring, } \\
\text { \% av } \\
\text { maksskåre }\end{array}$} & \multicolumn{3}{|c|}{ Utd.gruppe 1} & \multicolumn{3}{|c|}{ Utd.gruppe 2} & \multicolumn{3}{|c|}{ Utd.gruppe 3} & \multicolumn{3}{|c|}{ Utd.gruppe 4} \\
\hline & & & $\mathrm{N}_{\mathrm{K}}$ & $\begin{array}{l}\text { Gjennom- } \\
\text { snittlig } \\
\text { diff. i } \\
\text { endring, } \\
\% \text { av } \\
\text { maksskåre }\end{array}$ & & $\mathrm{K}$ & $\begin{array}{l}\text { Gjennom- } \\
\text { snittlig } \\
\text { diff. i } \\
\text { endring, } \\
\% \text { av } \\
\text { maksskåre }\end{array}$ & & $\mathrm{N}_{\mathrm{K}}$ & $\begin{array}{l}\text { Gjennom- } \\
\text { snittlig } \\
\text { diff. i } \\
\text { endring, } \\
\% \text { av } \\
\text { maksskåre }\end{array}$ & & $\mathrm{N}$ & $\begin{array}{l}\text { Gjennom- } \\
\text { snittlig } \\
\text { diff. i } \\
\text { endring, } \\
\% \text { av } \\
\text { maksskåre }\end{array}$ \\
\hline 1. Kjennskap til psykiske lidelser & $10,3 * *$ & 37 & 10 & $12,3 *$ & 96 & 35 & 1,99 & 75 & 36 & $10,53 *$ & 198 & 26 & $18,32 * *$ \\
\hline 2. Generell kunnskap om psykisk helse & $4,4^{*}$ & 19 & 5 & 0,33 & 59 & 23 & 5,27 & 48 & 20 & 6,74 & 119 & 12 & 4,97 \\
\hline $\begin{array}{l}\text { 3. Kunnskap om ulike diagnosers } \\
\text { ytringsformer }\end{array}$ & 1,8 & 42 & 10 & 3,01 & 106 & 36 & 0,03 & 79 & 36 & 0,05 & 211 & 26 & 2,3 \\
\hline $\begin{array}{l}\text { 4. Evne til kopling av symptomer til } \\
\text { diagnoser }\end{array}$ & $3,1^{*}$ & 33 & 9 & 3 & 95 & 34 & 2,46 & 69 & 34 & 4,03 & 199 & 24 & 2,84 \\
\hline 5. Tillit til behandlingsmetoder & $-3,5$ & 34 & 9 & 6,7 & 92 & 29 & $-7,8$ & 70 & 32 & 0,97 & 183 & 22 & $-6,46$ \\
\hline $\begin{array}{l}\text { 6. Kunnskap om hjelpapparatet innenfor } \\
\text { psykisk helse generelt }\end{array}$ & $11,6^{* *}$ & 31 & 9 & 11,6 & 85 & 31 & $8,78^{*}$ & 69 & 30 & $14,88 * *$ & 184 & 26 & $10,3 * *$ \\
\hline $\begin{array}{l}\text { 7. Kunnskap om nærmiljøets } \\
\text { hjelpeapparat innenfor psykisk helse }\end{array}$ & $11,3 * *$ & 39 & 10 & 5,73 & 104 & 35 & $10,13 *$ & 78 & 34 & $14,62 * *$ & 207 & 27 & $9,64 * *$ \\
\hline
\end{tabular}

Tabell 6. Skårer ved t1 blant elever med og uten måling før intervensjon.

\begin{tabular}{|c|c|c|c|c|c|}
\hline \multirow[b]{2}{*}{ Indekser: } & \multicolumn{2}{|c|}{ Gruppe 1 , med pretest } & \multicolumn{2}{|c|}{ Gruppe 3 , uten pretest } & \multirow[b]{2}{*}{$\begin{array}{l}\text { Sig. }(2- \\
\text { halet test) }\end{array}$} \\
\hline & $\begin{array}{l}\text { Gjennomsnitt } \\
\text { (absolutt skåre) }\end{array}$ & $\begin{array}{l}\text { Std. feil } \\
\text { for gj. }\end{array}$ & $\begin{array}{l}\text { Gjennomsnitt } \\
\text { (absolutt skåre) }\end{array}$ & $\begin{array}{l}\text { Std. feil } \\
\text { for gj. }\end{array}$ & \\
\hline 1. Kjennskap til psykiske lidelser & 5,91 & 0,12 & 3,87 & 0,19 & $0,001 * *$ \\
\hline 2. Generell kunnskap om psykisk helse & 9,44 & 0,11 & 8,78 & 0,18 & $0,018^{*}$ \\
\hline 3. Kunnskap om ulike diagnosers ytringsformer & 27,4 & 0,48 & 25,8 & 0,18 & 0,152 \\
\hline 4. Evne til kopling av symptomer til diagnoser & 16,46 & 0,30 & 13,06 & 0,50 & $0,001 * *$ \\
\hline 5. Tillit til behandlingsmetoder & 1,80 & 0,02 & 1,79 & 0,03 & 0,997 \\
\hline 6. Kunnskap om hjelpeapparatet innen psykisk helse generelt & 11,14 & 0,22 & 10,79 & 0,38 & $0,019^{*}$ \\
\hline $\begin{array}{l}\text { 7. Kunnskap om nærmiljøets hjelpeapparat innen psykisk } \\
\text { helse }\end{array}$ & 4,47 & 0,07 & 3,84 & 0,11 & $0,001 * *$ \\
\hline
\end{tabular}

tervensjonsgruppen har betydelig mer positiv utvikling på områdene kjennskap til psykiske lidelser, generell kunnskap om psykisk helse og kunnskap om hjelpeapparatet generelt og i nærmiljøet. Bakgrunnsdata viser at det er spesielt store utslag når det gjelder evne til å nevne ulike psykiske lidelser, kunnskap om hvilken hjelp helsesøster kan gi og kjennskap til spesialisthelsetjenesten. Men vi finner også signifikant større fremgang i kontrollgruppen om tiltro til fagfolks evne til behandling av psykiske problemer.

Som nevnt ovenfor, var det flere i intervensjonsgruppen enn i kontrollgruppen som hadde foreldre med høyeste universitetsutdanning. I tabell 5 er resultatene i tabell 3 brutt ned på subgrupper bestemt av fars utdanningsnivå. Det fremgår at den prosentvise effekten av intervensjonen er av samme størrelsesorden i de ulike gruppene. Men signifikansnivået reduseres fordi subgruppene er små. Grupperingen etter mors utdanningsnivå gir samme type mønster (ikke vist her).

I tabell 6 sammenliknes de i intervensjonsgruppen som fikk spørreskjema før intervensjon (gruppe 1) med de som ikke fikk det (gruppe 3). Gruppe 1 har signifikant høyere gjennomsnittscore på kjennskap til psykiske lidelser og kunnskap om psykiske helse, om hjelpeapparatet generelt og nærmiljøets hjelpetilbud. Gjennomføring av kunnskapsmåling forut for intervensjon synes altså å ha hatt noe effekt i seg selv på kunnskap ved t1.

\section{DISKUSJON OG KONKLUSJON}

Intervensjonsgruppen har klar framgang fra t0 til t1 på fem av syv indekser, og framgangen er signifikant større enn i kontrollgruppen når det gjelder kjennskap til psykiske lidelser, generell kunnskap om psykisk helse, evne til kopling av symptomer til diagnoser, kunnskap om hjelpeapparatet generelt og kunnskap om hjelpeapparatet i nærmiljøet. Observasjonene på indeksnivå støttes av observasjoner på enkeltleddnivå.

Kunnskapsmåling forut for intervensjon kan i seg selv ha effekt på senere kunnskap. Dette ble observert $\mathrm{i}$ en undersøkelse om seksualundervisning og kondombruk (13), og det samme er i noen grad tilfelle her. Dette er imidlertid en effekt som bare oppstår ved evaluering, der måling før intervensjonen er nødvendig. Effektene av selve VIP-intervensjonen er de som er anslått ovenfor. 
Det kan reises spørsmål ved prosjektets design. Ideelt sett skulle elevene i studien ha vært randomisert til henholdsvis VIP-intervensjon og ingen intervensjon. Det var ikke praktisk mulig. Vi kan således ikke utelukke at det var systematiske forskjeller mellom intervensjons- og kontrollgruppene knyttet til systematiske forskjeller mellom skoleelever $\mathrm{i}$ henholdsvis Akershus og Vestfold fylke. Mot dette taler imidlertid (a) at på de fleste registrerte kjennetegn var de to gruppene relativt like (tabell 2), og (b) at forskjellene mellom intervensjons- og kontrollgruppen holder seg $\mathrm{i}$ hovedsak når en kontrollerer for at utdanningsnivået $\mathrm{i}$ intervensjonsgruppen var høyere enn i kontrollgruppen.

Som nevnt tidligere finner vi signifikant større fremgang i kontrollgruppen om tiltro til fagfolks evne til behandling av psykiske problemer. Det er vanskelig å finne en god grunn til at det er slik. Fremgangen er ikke vesentlig. Det kan være et tilfeldig signifikant resultat $i$ et materiale der det er gjort svært mange sammenlikninger.

Effektene kan sammenliknes med resultater fra andre tilsvarende undersøkelser i Norge. Disse omfatter "Effektevaluering av opplæringsprogrammene Hva er det med Monica?, STEP - ungdom møter ungdom og Venn1.no" (18) og "Alle har en psykisk helse: Effektevaluering av en tredelt undervisningspakke for ungdomsskoletrinnet." (19-21). Effektstørrelsene ligger her mellom 0,01 og 0,3. I forhold til dette er effekten av VIP betydelig. I internasjonale undersøkelser, herunder både longitudinelle studier (22) og kunnskapsoppsummeringer om universelle forebyggende intervensjoner vedrørende depresjon (23) og psykisk helse
(24-26), varierer de aktuelle sammenliknbare effektstørrelsene mellom 0,26 til 0,57. Også i forhold til dette synes effekten av VIP å være god. I mange av de internasjonale studiene som er benyttet i sammenlikning av resultater har aldersgrupperingene vært 5-7, 8-11 og 12-16 år. Der har man også generelt sett funnet at jo eldre elevene er, desto mindre er sjansen for effekt (27).

Om de observerte forskjellene er tilfredsstillende, er en vurderingssak. VIP-programmet består av noen undervisningstimer på skolen, dialog med fagpersoner, og noen egenstudier. Med undervisningstimer må en generelt kunne forvente at kunnskap kort tid etter som her ved $\mathrm{t} 1$ - er høyere enn den var forut for undervisningen. Det gjelder enten det er engelsk, matematikk, geografi eller psykisk helse det undervises i. På den annen side er VIP-programmet et ekstraordinært utenomfaglig innslag i undervisningen, og det er uten eksamen, slik at man kanskje må forvente mindre læring her enn i fag som elevene skal ha på vitnesbyrdet. Vår samlede vurdering er at når intervensjonsgruppen på indeksene "kunnskap om hjelpeapparatet generelt", "kunnskap om hjelpeapparatet lokalt", "kjennskap til psykiske lidelser" og "generell kunnskap om psykisk helse" har hatt en merframgang i forhold til kontrollgruppen på henholdsvis $11,6,11,3,10,3$ og 4,4 prosentenheter, er dette et nokså moderat resultat.

Kunnskap forvitrer og glemmes over tid, og det gjenstår å se om VIP-programmet får varige effekter av en størrelsesorden som er tilfredsstillende, sett i forhold til det programmet koster. Dette vil være en problemstilling for senere artikler, der effekter etter 6 , 12, og 24 måneder vil bli rapportert.

\section{REFERANSER}

1. Sosial- og helsedepartementet. Faktarapport om årsaker til psykiske plager og lidelser, 2000.

2. Nasjonalt kunnskapssenter for helsetjenesten. Helseprofil for barn og ungdom i Akershus - Ungdomsrapport, 2004; 2: 102-139.

3. Nasjonalt Folkehelseinstitutt. Rapport 2009:1 13-15 åringer fra vanlige familier i Norge - hverdagsliv og psykisk helse. Nordberg trykk as, Oslo, 2009: 1. www.fhi.no/eway/default.aspx?pid=233\&trg=MainLeft 5565\&MainArea 5661=5565:0:15,2336:1:0:0:::0:0\&MainLeft 5565=5603:73517::1:5793:1:::0:0.

4. Feldman, MA [E]]. Early intervention: The essential readings. Malden: Blackwell Publishing, 2004: $214-235$.

5. Kupfer DJ, Frank E, Perel JM. The advantage of early treatment intervention in recurrent depression. Arch Gen Psychiatry 1989; 9: 771-775.

6. Jørgensen P, Larsen TK. Rosenbaum B. Tidlig indsats ved skizofreni - Utvikling og behandling. København, Fadl's Forlag, 2000: 93-104.

7. Aronen ET, Arajärvi T. Effects of early intervention on psychiatric symptoms of young adults in low-risk and high-risk families. Am J Orthopsychiatry 2000; 2: 223-232.

8. Mentore JL. The effectiveness of early intervention with young children "at risk": A decade in review. Dissertation Abstracts International: Section B: The Sciences and Engineering 2000: 7-B.

9. VIP. http://www.vipweb.no/INDEX2.HTML, Blakstad sykehus, Trykkeriet, 2010.

10. Heyerdahl S. SDQ - Strength and Difficulties Questionnaire: En orientering om et nytt spørreskjema for kartlegging av mental helse hos barn og unge, brukt i UNGHUBRO, OPPHED og TROFINN. Norsk Epidemiologi 2003; 1: 127-135.

11. Statistisk Sentralbyrå. Årbok 2006. http://www.ssb.no/aarbok 2006. 
12. Pedhazur EJ, Schmelkin LP. Measurement, Design, and Analysis. Hillsdale, New Jersey, Lawrence Erlbaum Publishers, 1991.

13. Kvalem IL, Sundet JM, et al. The effect of sex education on adolescents' use of condoms: applying the Solomon four-group design. Health Educ Q 1996; 23:33-47.

14. Goodman R, Meltzer H, Bailey V. The Strengths and Difficulties Questionnaire: A pilot study on the validity of the self-report version. Eur Child Adolesc Psychiatry 1998; 7: 125-130.

15. Mathisen KS, 2010. http://www.fhi.no/eway/default.aspx?pid=233\&trg=MainArea_5661\&MainArea_5661= 5565:0:15,4333:1:0:0:::0:0\&MainLeft_5565=5544:61134::1:5569:3:::0:0.

16. VIP, bakgrunnsdokumenter 2009/2010 for forskningsprosjektet. http://www.fhi.no/eway/default.aspx?pid= 233\&trg=MainArea_5661\&MainArea_5661=5631:0:15,4678:1:0:0:::0:0

17. Cohen J. Statistical power analysis for the behavioural sciences (2nd edition). Hillsdale, NJ: Erlbaum, 1988.

18. Andersson HW, Kaspersen SL, Bungum B, Bjørngaard JH, Buland T. Psykisk helse i skolen. Effektevaluering av opplæringsprogrammene, Hva er det med Monica?, STEP - ungdom møter ungdom og Venn1.no. A1491. Sintef 2010. http://www.sintef.no/upload/Teknologi_samfunn/Rapport\%20A14919\%20Psykisk\%20 helse $\% 20 \mathrm{i} \% 20$ skolen $\% 20-\% 20$ Sluttrapport.pdf.

19. Wang CE, Skre I, Lindekleiv Magnus RE. Alle har en psykisk helse. Oppsummering etter en treårig effektevaluering gjennomført av Institutt for psykologi ved Universitetet i Tromsø, 2008.

20. Tobiassen AG, Magnus RE, SlettliGundersen L. Alle har en psykisk helse: effektevaluering av en tredelt undervisningspakke for ungdomsskoletrinnet, 2. del, Self-efficacy og mestring. Universitetet i Tromsø, 2006.

21. Arnesen Y, Breivik C, Johnsen LI. Alle har en psykisk helse: effektevaluering av en tredelt undervisningspakke for ungdomsskoletrinnet: første del. Universitetet i Tromsø, 2005.

22. Spence S, Sheffield JK, Donovan CL. Long-term outcome of a school-based, universal approach to prevention of depression in adolescents. J Consult Clin Psychol 2005; 1: 160-167.

23. Merry SN, McDowell HH, Hetrick SE, Bir JJ, Muller N. Psycological and/or educational interventions for the prevention of depression in children and adolecents. The Cochrane Collaboration. Wiley \& Sons, 2000: 2.

24. Dulak JA, Wells AM. Primary prevention mental health programs for children and adolescents: a metaanalytic review. Am J Community Psychol 1997; 2: 115-152.

25. Weisz JR, Sandler IN, Durlak JA, Anton BS. Promoting and protecting youth mental health through evidencebased prevention and treatment. Am Psychologist 2005; 6: 628-648.

26. Weist MD, Albus KE, et al. Expanded school mental health. Behav Modif 2004; 4: 463-616.

27. Browne G, Gafni A, Roberts J, Byrne C, Majumdar B. Effective /efficient mental health programs for schoolage children: a synthesis of reviews. Soc Sci Med 2003; 7: 1367-1348. 